\title{
Horbulák Zsolt
}

\section{Munkanélküliség Szlovákia déli régióiban}

\section{Unemployment in the Southern Regions of Slovakia}

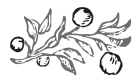

\section{Összefoglalás}

A szlovák gazdaság és társadalom rendszerváltozás óta tartó egyik legjelentősebb problémája a magas munkanélküliség, különösen a pályakezdók, illetve bizonyos etnikai csoportok körében, valamint elsôsorban Dél-Szlovákia, továbbá Kelet-Szlovákia néhány vidékén. A tanulmány célja bemutatni Szlovákia déli régióinak munkanélküliségi helyzetét, és választ keresni e gazdasági-társadalmi jelenség okaira. Dél-Szlovákia határ menti, jelentős magyar lakossággal rendelkezô régióinak adatait vizsgálva megállapítható, hogy aggregált munkanélkülisége hosszú távon meghaladja az átlagos szlovák munkanélküliségi rátát. A negatív adatokat kisebb ipari kibocsátás, alacsonyabb bérek, kisebb termelékenység, az iskolázottság alacsonyabb színvonala, továbbá rosszabb demográfiai és egészségügyi mutatók indokolhatják.

Journal of Economic Literature (JEL) kódok: J40, J60, R23

Kulcsszavak: munkanélküliség, foglalkoztatás, Szlovákia, Dél-Szlovákia

\section{Summary}

One of the most significant problems of the Slovakian economy and society since the change of regime has been high unemployment rates among young career starters and certain ethnic groups, especially in Southern and Eastern Slovakia. The main purpose of this paper is to describe unemployment in the southern regions of Slo-

Horbulák Zsolt PhD, adjunktus, Selye János Egyetem, Komárom (horbulakz@ujs.sk). 
vakia and to seek an answer to this economic and social phenomenon. An analysis of the data collected along the Southern borders, where a significant number of Hungarian nationalities live suggests that over the long term the aggregate unemployment rate exceeds the average unemployment rate for Slovakia. The reasons for these adverse data may include lower industrial output, lower wages, lower productivity, the lower educational level of inhabitants and worse demographic and health indicators.

Journal of Economic Literature (JEL) codes: J40, J60, R23

Keywords: unemployment rate, employment rate, Slovakia, Southern Slovakia

\section{BEVEZETÉS}

A rendszerváltozás utáni harmadik évtizedre Szlovákia Közép-Európa gazdaságilag egyik legsikeresebb államává vált. Gazdasági növekedése magas, eladósodottságnak mértéke az eurózóna átlaga alatt van, folyamatos a külföldi tóke beáramlása, az ország legsikeresebb ágazata, a gépjármúgyártás egyre jobb mutatókkal rendelkezik (Horbulák, 2019), a reálkonvergenciát tekintve pedig az ország folyamatosan felzárkózik az Unió átlagához, és középtávon várható a gazdasági növekedés fennmaradása (Nagy, 2015). Mindezt azért érdemes hangsúlyozni, mivel nem sokkal a rendszerváltást követően, Csehszlovákia kettéválása után, Szlovákia társadalmi-politikai fejlôdése megrekedt. A belpolitikai életben permanens válság uralkodott, a korrupció felerôsödött, a gazdasági életben a piaci mechanizmusok helyett a személyes ismeretségen alapuló kapcsolatok érvényesítése dominált. Mindezek folyományaként Szlovákia euroatlanti integrációja is lefékeződött (Leško, 1998). 1998 után két választási ciklusban jobboldali kormánykoalíció került hatalomra, amely több átfogó reformot hajtott végre (új Munka törvénykönyve, nyugdíjreform, adóreform stb.), amelyek következtében az ország a külföldi befektetők kedvelt célpontjává vált. A kétezres években volt olyan esztendô, amikor a GDP éves növekedése meghaladta a 10\%-ot. A számos kiváló gazdasági mutató mellett azonban egy indikátor esetében Szlovákia hosszú távon elmarad valamennyi szomszédjától, és összeurópai tekintetben az egyik legrosszabb pozícióval rendelkezik, ez pedig a munkanélküliségi ráta alakulása.

Ebben a tanulmányban Szlovákia munkanélküliségi mutatóit elemezzük, különös tekintettel a déli régióra. A témaválasztás oka, hogy ennek a vidéknek a lakossága jelentôs mértékben magyar anyanyelvú. ${ }^{1}$ A tanulmányban felvázoljuk Szlovákia általános foglalkoztatási helyzetét, majd szólunk Szlovákia regionális foglalkoztatásáról, közigazgatási felosztásáról, Dél-Szlovákia meghatározásának a megközelítéseirôl, bemutatjuk Dél-Szlovákia munkanélküliségi helyzetét, végül néhány válogatott mutató segítségével megpróbálunk választ adni a régió foglalkoztatási problémáinak okára. 
SZLOVÁKIA MUNKAERôPIACI HELYZETE

A munkanélküliség Szlovákiában a rendszerváltozás óta komoly gondot jelent. Mértéke az 1990-es évektól folyamatosan magas, javulás csak a 2010-es évek második felétól tapasztalható. Az 1. ábra az ország munkanélküliségi adatait közvetlen szomszédai, Lengyelország, Csehország, Magyarország és Ausztria, továbbá az EU25 tagállamok munkanélküliségi rátájával veti össze.

1. ábra: A V4-országok, Ausztria és az EU25-ök átlagos munkanélküliségi rátája (\%)

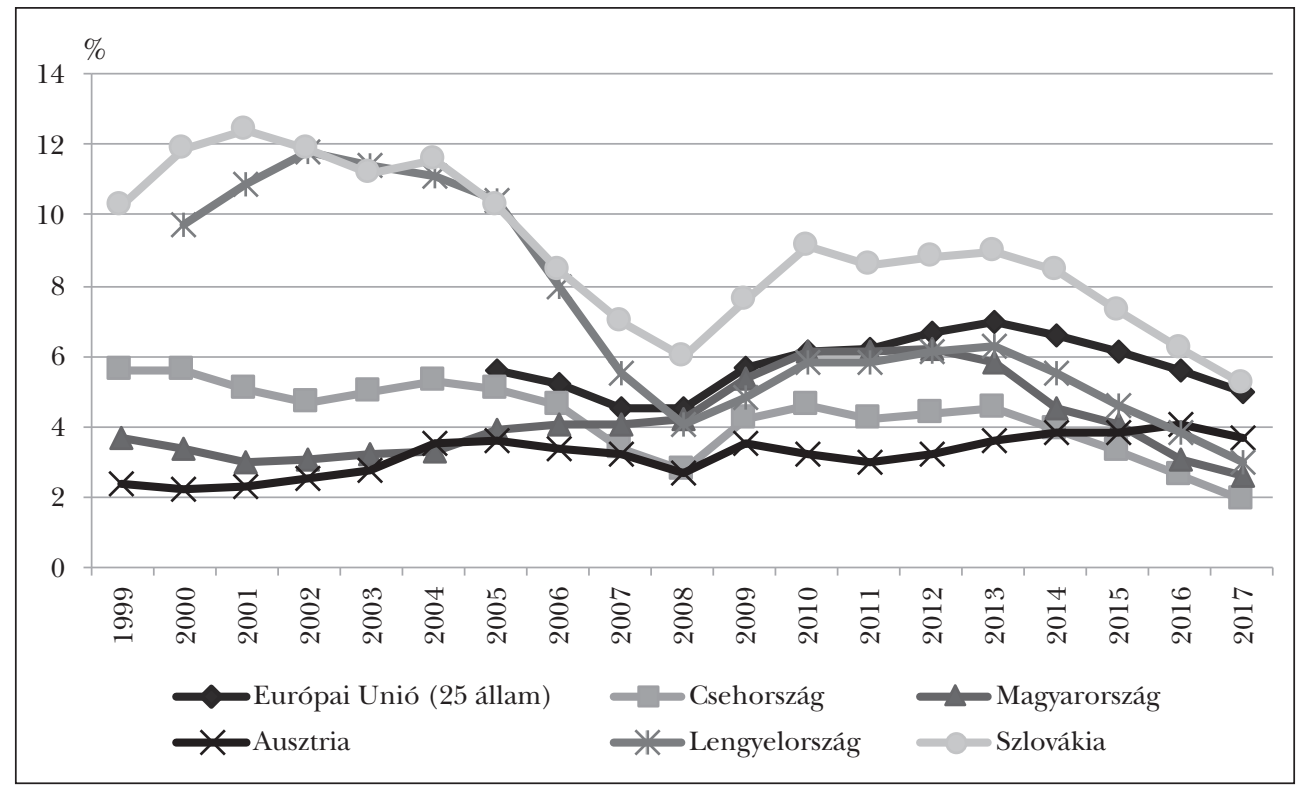

Forrás: Saját szerkesztés az Eurostat adatai alapján

Az 1. ábra jól mutatja, hogy a vizsgált időszakban Szlovákia egy évet kivéve mind a régióban, mind pedig az Európai Unióban folyamatosan az egyik legmagasabb munkanélküliséggel rendelkezó országok közé tartozott. Csupán egy alkalommal sikerült megelôznie egy országot, 2003-ban, amikor 0,2\%-kal voltak jobb adatai, mint Lengyelországnak.

A problémakörről Magyarországon is jelent meg elemzés (Nagy, 2016), amely szintén megállapítja, hogy „a munkanélküliség mindig is Szlovákia legmeghatározóbb társadalmi problémája volt". Ennek számos oka van. A teljesség igénye nélkül Nagy megemlíti a szlovák gazdaság túlzott hadiipari kitettségét a rendszerváltozás idején, Csehszlovákia kettéválását, a mečiari politikai korszakot, továbbá azt, hogy „a szlovák gazdaság kardinális problémái termékek árbeli konkurenciaképességén alapuló tényezők elpárolgásában nyilvánultak meg, ugyanakkor nem fejlődtek ki kellóképpen a nélkülözhetetlen intézményi, rendszeri és tárgyi feltételei a nem árjellegú konkurenciaképességen alapuló termelésre való áttérésnek”. Egy másik szerző a rossz statisztikai adatok mögött a következó befolyásoló tényezóket látja (Pongrácz, 2018:39): 
- a munkanélküliség nagy regionális egyenlőtlenségei;

- a fiatalok magas munkanélkülisége;

- a tartós munkanélküliség magas aránya;

- az alacsonyan képzett munkaerô magas száma;

- a szakképzett munkaerô hiánya egyes ágazatokban;

- a roma kisebbség óriási munkanélkülisége.

Azt, hogy a munkanélküliség Szlovákia egyik legjelentôsebb gazdasági és társadalmi problémája, hasonlóképpen látják a szlovák elemzók is (Kureková, 2010). A tanulmány kiemeli, hogy jelentôsek a regionális eltérések; a magas munkanélküliség a konjunktúra idején is megmarad; az állástalanság leginkább az alacsony képzettségúeket és a fiatalokat érinti; a válságok idején jelentôsen emelkedik a közfoglalkoztatottak aránya; nagyon alacsony az egyéb foglalkoztatási formák aránya; az új dolgozók alkalmazását bürokratikus akadályok nehezítik; alacsony a munkaerô mobilitása; hiányzik a munkahelyteremtési intézkedések hatékonyságának a vizsgálata; illetve sikertelen a marginalizált csoportok bevonása a munkaerôpiacra.

A 2. ábra a korosztályos munkanélküliségi adatokat szemlélteti, és igazolja a fentebb leírt tényeket. A négy bemutatott korcsoport a pályakezdôk, a munkavállalók fiatalabb, illetve idôsebb korosztálya, valamint a nyugdíj elôtt állók. Az ábra érzékelteti a szlovákiai foglalkoztatási helyzet igazi problémáját, ami a pályakezdôk kiemelkedôen rossz munkanélküliségi mutatója. A jelenség akutnak tekinthetô, mivel a rendszerváltozás után azonnal megjelent, és máig sem sikerült igazán orvosolni. Az, hogy az iskolapadból kikerülóknek nagyon nehéz állást találniuk, komoly hatással van életpályájukra, és romboló hatással van az egész társadalom moráljára.

2. ábra: A 20-24, 35-39, 45-49 és az 55-59 éves korosztályok munkanélküliségi rátája (\%)

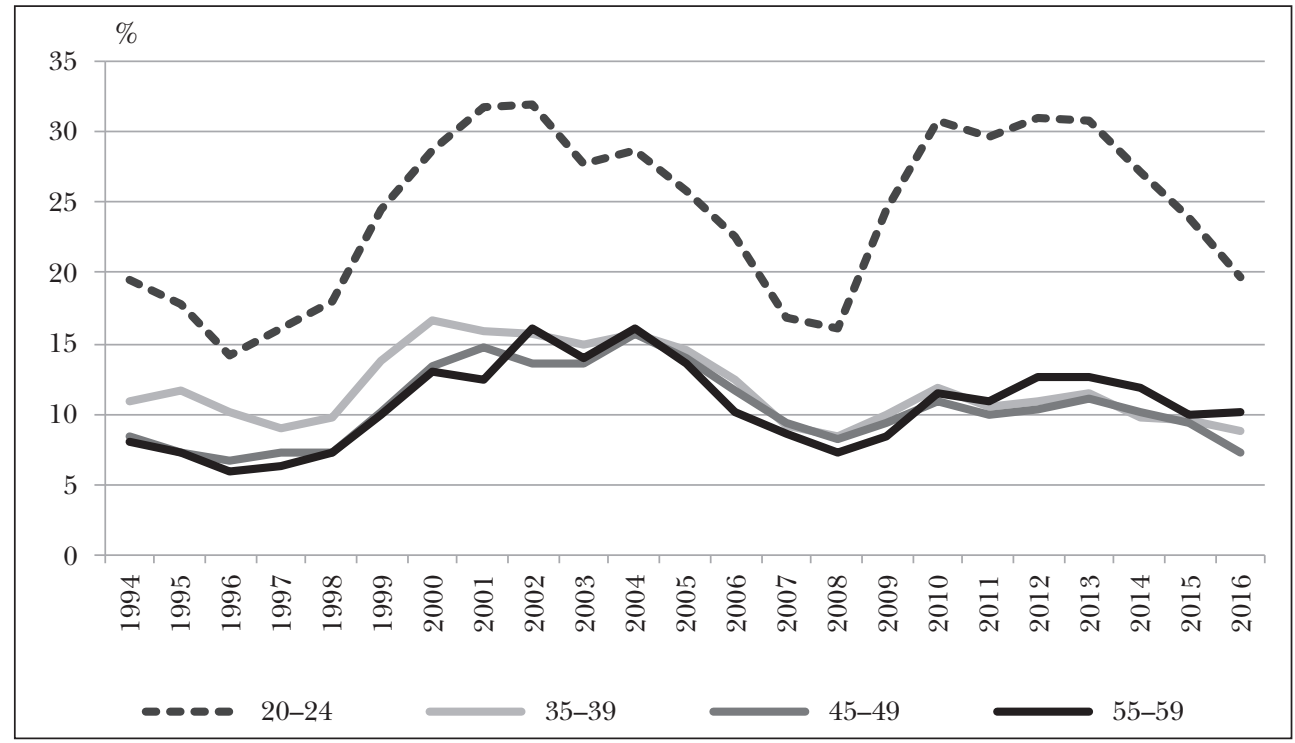

Forrás: Saját szerkesztés a Szlovák Statisztikai Hivatal (www.statistics.sk) adatai alapján 
Az ágazati foglalkoztatottságot tekintve Szlovákiában 2016-ban az alkalmazottak közel 21\%-a, 482500 fố dolgozott az iparban. Ez az érték az utóbbi másfél évtizedet figyelembe véve, abszolút számokat tekintve stagnál, százalékosan viszont közel 3,5\%-os visszaesést jelent. A mezőgazdaságban dolgozók aránya már nem éri el a 4\%-ot, miközben 16 éve még majdnem kétszer ennyien dolgoztak az agráriumban. Hasonló arányban szorult vissza a bányászatban dolgozók aránya. 2000 óta közel a duplájára nôtt a múvészet, szórakoztatás, üdültetés szektorban dolgozók aránya, de összességében még mindig csak a foglalkoztatottak 2,2\%-a áll alkalmazásban ebben a perspektivikus ágazatban. Az adminisztratív és támogató szolgáltatásoknál, vagyis a piaci szolgáltatások esetében másfél évtized alatt jóval 50\%-os a bôvülés, de megközelítôen ilyen arányú, 57\%-os a növekedés az államigazgatásban is. Az oktatásban mintegy 13400 fóvel kevesebben dolgoznak, ellenben a piaci jellegú kutatásokban pontosan kétszer annyian voltak alkalmazásban 2016-ban, mint 2000-ben.

A foglalkoztatáshoz szorosan kapcsolódik a bérezés is. Az utóbbi két-három évtizedben, 2016-ig bezárólag a nominálbérek Szlovákiában közel a hét és félszeresükre emelkedtek, 728\%-kal 25,14 euróról 910 euróra nôttek. A rendszerváltozás óta gyakorlatilag minden évben nominálbér-növekedés következett be. Szlovákiában magasnak tekinthetô infláció legfeljebb csak 1991-ben és 1992-ben volt, ezért jelentôs reálbércsökkenésre csak 1991-ben került sor, mégpedig 28,7\%-osra. Kisebb csökkenés késóbb is elófordult, 1993-ban 3,9\%-os, 1999-ben 3,1\%-os, 2000-ben 4,9\%-os, 2003-ban 2\%-os, 2011-ben és 2012-ben 1,6\%-os, illetve 1,2\%-os volt. A visszaesések az átfogó gazdasági reformhoz (1998-2000) vagy a gazdasági válságokhoz (1990-1992, 2009) köthetôk. Mindent összevetve azonban a szlovákiai bérek reálértékben 1990 óta 30\%-kal nôttek.

\section{3. ábra: A nominálbér és a reálbér alakulása Szlovákiában (euró, \%)}

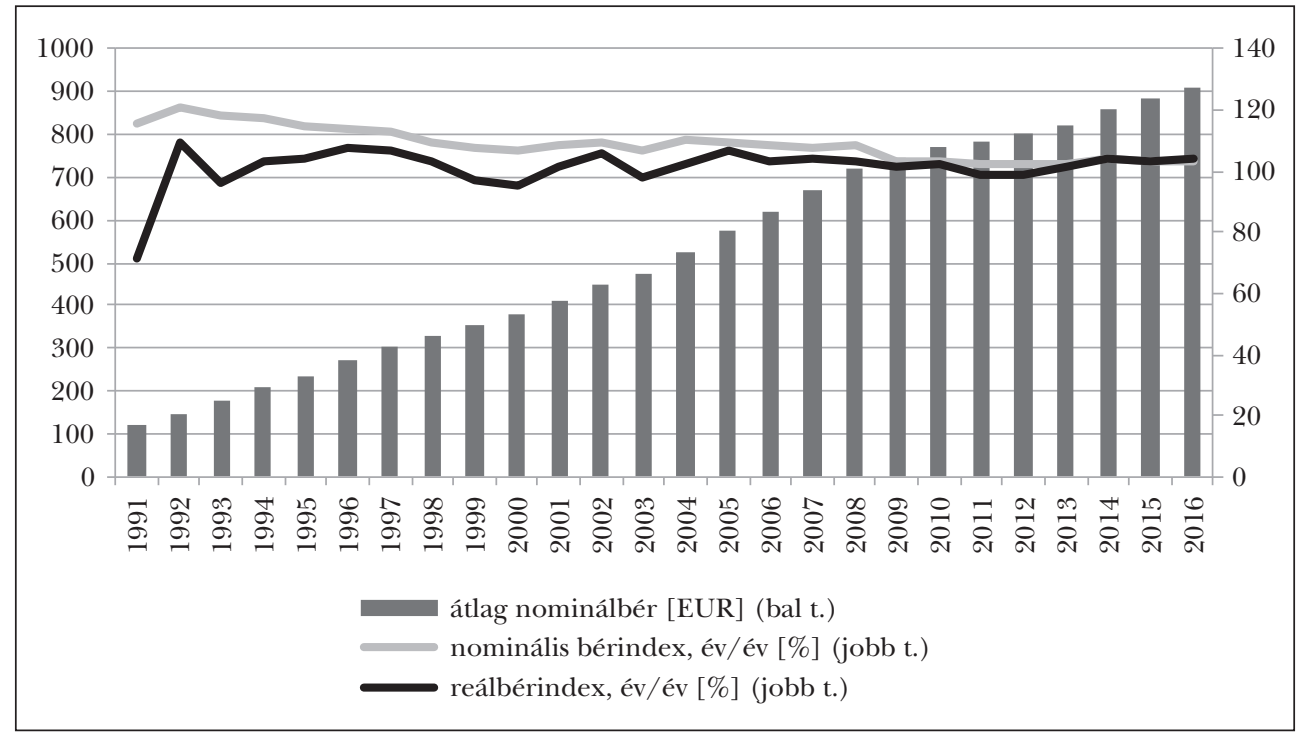

Forrás: Saját szerkesztés a Szlovák Statisztikai Hivatal (www.statistics.sk) adatai alapján 
A bemutatott statisztikai adatok azt jelzik, hogy Szlovákia gazdasága egy fejlôdô gazdaság, foglalkoztatási struktúrája javul, a bérek emelkednek, a munkanélküliség csökken, ám nem egyforma mértékben, és továbbra is jelentôs mértékben sújtja a fiatalabb korosztályokat.

\section{REgIONÁlis FOGLALKOZTATÁSI KÖRKÉP}

A következókben a szlovákiai munkaerópiaci helyzetet regionális szinten tekintjük át. Az 1. táblázat arra a tényre mutat rá, hogy gazdasági szempontból Szlovákia két részre szakadt, a fôvárosra és az agglomerációjára, illetve az ország többi részére. A sokak által irigyelt pozsonyi NUTS2² régió, amely az Unió tíz gazdaságilag legerôsebb régiója között szerepel, és Prága kivételével lehagyja a V4-országok fôvárosi régióját is, tulajdonképpen csak egy szigetnek tekinthető, melynek bár növekvő, de továbbra is csekély hatása van az ország többi részére.

\section{1. táblázat: Szlovákia NUTS2 régióinak vásárlóerô-paritáson mért ereje (2017)}

\begin{tabular}{l|l|c}
\hline Kód & \multicolumn{1}{|c|}{ NUTS2 régió } & Az EU-átlag \%-os aránya \\
\hline SK01 & Bratislavský kraj (Pozsonyi kerület) & 179 \\
\hline SK02 & Západné Slovensko (Nyugat-Szlovákia) & 70 \\
\hline SK03 & Stredné Slovensko (Közép-Szlovákia) & 61 \\
\hline SK04 & Východné Slovensko (Kelet-Szlovákia) & 54 \\
\hline
\end{tabular}

Forrás: http://ec.europa.eu/eurostat

A regionális különbségek kérdésköre Szlovákiában jól ismert és kutatott jelenség (Rievajová-Klimko, 2018; Menbere Workie-Štefánik, 2014; Michálek-Podolák, 2014; Švecová-Rajčáková, 2014). Tény, hogy Szlovákiában ezek a különbségek nagyok, és mérhetôen magasabbak, mint a volt társállam nyugati felében, Csehországban (Koišová et al., 2018). Vannak olyan vidékek is, ilyen a Besztercebányai kerület, ahol a belsố különbségek nemhogy nem csökkennek, hanem még tovább mélyülnek (Liptáková, 2017). Összefoglalva elmondható, hogy „Szlovákia gazdasági fejlettsége rendkívül sajátos. Az ország legnyugatibb pontján található Pozsony és szúkebb környezetének fejlettsége mellett kelet felé haladva egyre fejletlenebb területekkel találkozhatunk" (Mezei-Hardi, 2003:136). „A régiók munkanélküliségi adatait összegezve: a vizsgált déli régiók a [foglalkoztatás] tekintetében a legrosszabb helyzetú térségek közé tartoznak. A helyzet elsôsorban a gömöri-kishonti-nógrádi régióban és Zemplénben a leginkább kritikus" (Fazekas-Hunčík, 2004:302).

Ha a kerületek munkaerôpiaci helyzetét vizsgáljuk, a következô kép tárul elénk. Az országos átlagnál jobb aktivitási ráta a Pozsonyi kerület mellett még a Nagyszombati és a Besztercebányai kerületben van. Ami a foglalkoztatást illeti, csak a két keleti kerület, az Eperjesi és a Kassai nem éri el az országos átlagot. Végül a munkanélküliségi ráta is kirajzolja a kelet-nyugat szembenállást, országos átlag feletti értékkel a Besztercebányai, Kassai és Eperjesi kerület rendelkezik. 
4. ábra: Gazdasági aktivitás, foglalkoztatás és munkanélküliség kerületi szinten (\%, 2017)

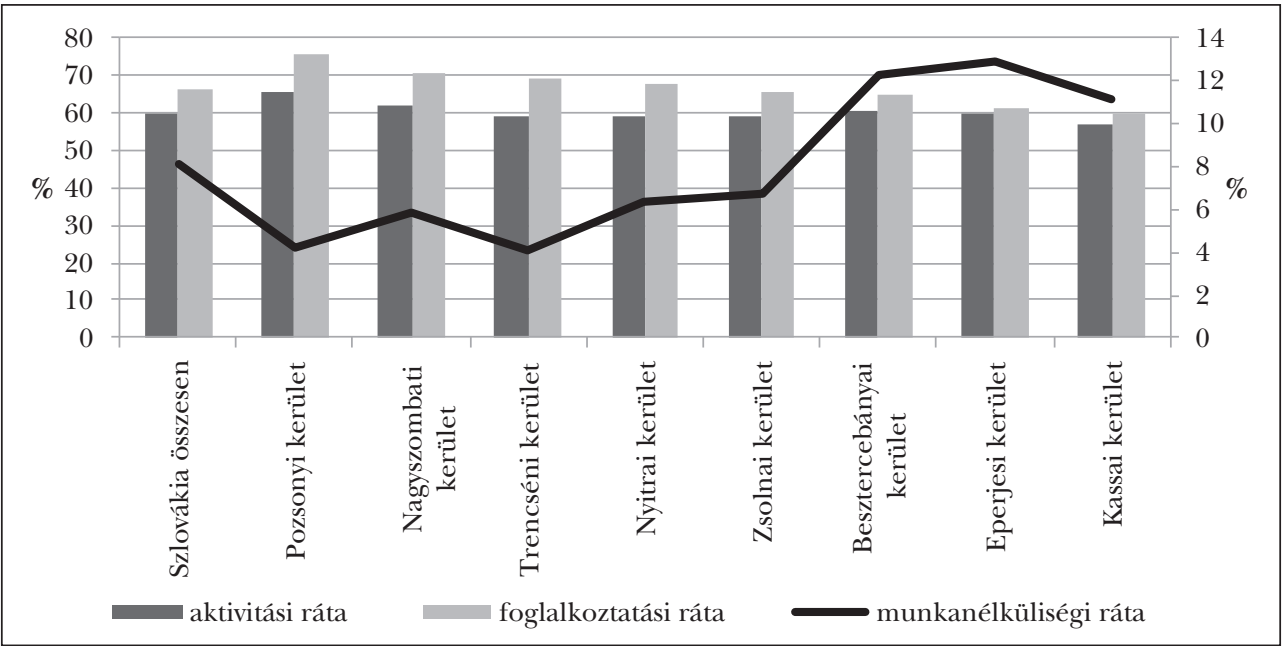

Forrás: Szlovákia regionális statisztikai évkönyve 2018

A munkanélküliséget tekintve az ország akut problémája az, hogy vannak bizonyos térségek, ahol a munkanélküliség makacsul magas szinten áll. Ha a még eggyel alacsonyabb közigazgatási szintet, a járást (LAU1) vesszük alapul, 2017 decemberében a munkanélküliségi ráta a következô járásokban haladta meg az országos érték $(11,88 \%)$ kétszeresét (2. táblázat).

2. táblázat: Az országos átlag dupláját meghaladó járások Szlovákiában

\begin{tabular}{l|c|c}
\hline Járás & Munkanélküliségi ráta (\%) & Az országos érték aránya \\
\hline Poltár & 12,84 & 2,16 \\
\hline Nagyrốce & 14,88 & 2,51 \\
\hline Rimaszombat & 18,48 & 3,11 \\
\hline Bártfa & 11,91 & 2,01 \\
\hline Késmárk & 15,44 & 2,60 \\
\hline Mezőlaborc & 12,83 & 2,16 \\
\hline Kisszeben & 12,20 & 2,05 \\
\hline Felsóvízköz & 12,73 & 2,14 \\
\hline Varannó & 13,61 & 2,29 \\
\hline Gölnicbánya & 12,69 & 2,14 \\
\hline Kassa vidék & 12,12 & 2,04 \\
\hline Rozsnyó & 16,23 & 2,73 \\
\hline Szobránc & 12,93 & 2,18 \\
\hline Tóketerebes & 13,63 & 2,29 \\
\hline
\end{tabular}

Forrás: Saját számitás a Munkaügyi, Szociális és Családügyi Hivatal (www.upsvr.sk) adatai alapján 
Szlovákia 72 járása közül tizennégyben haladta meg a munkanélküliség az országos átlag kétszeresét. Ez a tizennégy alacsonyabb szintú közigazgatási egység két régióban található, mégpedig Dél-Szlovákia középsô térségének déli és keleti részén, illetve északkeleten. A déli, nagy részben Magyarországgal határos és külön-külön is jelentôs számú magyar lakosságú tizenhat járás közül öt tartozik a foglalkoztatás szempontjából a leginkább hátrányos járások közé. A legrosszabb helyzetben lévô vidékeket a köznyelv „éhségvölgyeknek” nevezte el. Ilyen országrész többek között Gömör, azaz a Nagyrốcei és Rimaszombati járások.

\section{DÉL-SzLOVÁKIA MEGHATÁROZÁSA}

A legfontosabb kérdés, amelyet elsôként meg kell válaszolni, az, hogy mit nevezünk Dél-Szlovákiának, miként lehet földrajzilag behatárolni a vizsgált területet? Dél-Szlovákiának hagyományosan a magyarlakta vidéket szokás nevezni, és ez a térség Szlovákia egész déli határa mentén húzódik végig hol széles, hol beszúküló sávban. Ezt a felfogást még az ország többségi nemzete is elfogadja, noha „magyarlakta” vidék helyett napjainkra inkább a „vegyes lakosságú terület” kifejezést használja.

A probléma gyökere a szlovák közigazgatási felosztásban rejlik. A szakirodalomban (Süli-Zakar, 2003) elfogadott az a nézet, hogy vannak természetes, szerves úton létrejött régiók, és vannak szándékoltan, állami-politikai akaratból létrejött régiók. E kettôsség miatt beszélünk regionalizálódásról, amikor az alapvetô társadalmi-gazdasági folyamatok, érdekek alapján a települések, kisebb-nagyobb téregységek között magas fokú integráció jön létre, és beszélünk regionalizálásról, amikor intézményi szinten irányított és szabályozott közigazgatási-politikai folyamatról van szó. A kérdéskörrôl magyar nyelven megjelent szakirodalom (Mezei-Hardi, 2003; Mezei, 2005; Gulyás, 2008) rámutat arra, hogy az etnikai elv bármilyen szintú figyelembevételére nem került sor Szlovákia közigazgatási átalakításainak idején, sôt a magyar kisebbség szempontjából rendkívül hátrányos közigazgatási felosztásokat határoztak meg. Ennek eredményeként mind a szocializmus idején, mind pedig a rendszerváltozás után olyan közigazgatási egységeket hoztak létre, amelyekben csak minimális esetben sikerült abszolút magyar többséget elérni.

A volt Csehszlovákiában és a mai Szlovákiában a közigazgatási rendszer kétszintú, a nagyobb területi egység a kerület, a kisebb a járás. Az utolsó csehszlovák közigazgatási felosztás idején a négy kerület közül egynek sem volt magyar többsége, a 38 járásból kettô lett abszolút magyar többségú. A jelenlegi felosztás szerint 8 kerület és 72 járás van, de magyar többségú továbbra is csak kettô. Mindebbôl következôen nehéz megállapítani, miként lehet Szlovákiában kijelölni közigazgatásilag is behatárolható, magyarok által lakott vidéket.

A legegyszerúbb megoldás, amelyet szinte minden esetben a szakirodalom is használ, a szlovák közigazgatási egységekből való kiindulás. Szlovákia legutóbbi, 1996-ban végrehajtott közigazgatási felosztása során az országot 8 kerületre, ezen belül 79 járásra osztották. A járások tényleges száma ennek ellenére 72, ugyanis Pozsony és Kassa önmagában öt, illetve négy járásra oszlik. Késôbb a járások mint közigazgatási egysé- 
gek ugyan megszúntek, de mint statisztikai egységek továbbra is léteznek. A munkanélküliségi rátát, a szociális támogatásokban részesülők arányát, a külföldi munkavállalók számát stb. havi rendszerességgel közlik. Ennek a módszernek a hátránya, hogy a határaikat úgy húzták meg, hogy közülük csupán kettôben, a Dunaszerdahelyi és Komáromi járásban él a magyarság abszolút többségben, a többi járásban változó az arányuk. Másként fogalmazva, a déli rész abszolút magyar többsége az északi rész abszolút szlovák többségével képez egy statisztikai egységet, miközben két kivételtôl eltekintve az egész járás szlovák többségú. A 16 járásban a felvidéki magyarság összességében így jelentôs kisebbségben van.

Dél-Szlovákia meghatározásának további lehetôsége, amit a szlovákiai magyar nyelvú szakirodalom (pl. Fazekas-Hunčík, 2004) gyakran használ, a határ menti történelmi-néprajzi tájegységek (Csallóköz, Mátyusföld, Gömör stb.) összessége. Mivel ezek nem statisztikai egységek, így gazdasági elemzések esetében csak jelentôs fenntartással használhatók.

Dél-Szlovákiában tizenhat olyan járás van, amely jelentôs magyar lakossággal rendelkezik. E tizenhat járáshoz hozzá lehet számítani Pozsonyt és Kassát, amelyek magyarsága arányait tekintve szinte jelentéktelenné zsugorodott, ellenben továbbra is fontos magyar központok maradtak. A Nyitra járásban található Zoboralján a magyarság asszimilációja szintén nagyon előrehaladott, de a szlovákiai magyar nyelvú szakirodalom (pl. Gyurgyík, 1994) ezt a vidéket is a magyar régiók között tartja számon.

Az említett járásokat és városokat együttesen a következóképpen lehet jellemezni:

- a déli járások és a két város kiterjedése együtt 16588,5 km², ez az ország területének 33,83\%-a;

- a 16 járás kiterjedése Pozsony és Kassa nélkül 15 983,7 km², ami az ország területének $32,6 \%$-a;

- a 16 járásban és a két városban élők száma 2149424 fô, ez Szlovákia lakosságának $32,83 \%$-a;

- csak a 16 járásban élook száma 1497763 fő, ez az ország lakosságának 27,75\%-a;

- a 16 járásban, illetve Pozsonyban és Kassán 2011-ben 453240 fő vallotta magát magyarnak, ami az adott terület lakosságának a 21,09\%-a, a felvidéki magyarság 98,86\%-a;

- csak a 16 járásban 432739 magyar ember él, ami az összlakosság 28,89\%-át teszi ki, és a szlovákiai magyarságnak 94,39\%-át.

Az elmondottakból következik, hogy a szlovákiai magyarság döntô része az ország déli járásaiban, a szülőföldjén él. A közigazgatási felosztás ellenére a magyarság ezt a területet egységnek tekinti.

\section{DÉL-SzLovákia FOGLALKOZTATÁSI HELYZETE}

Ahogy azt fentebb írtuk, a tizenhat dél-szlovákiai járásból öt tartozik a munkaerôpiaci szempontból hátrányos helyzetú járások közé. Mindez azt jelenti, hogy a Dél-Szlovákia 16 járásában élő magyarság 21,8\%-ának kell szembesülnie foglalkoztatási jellegú problémákkal. Amennyiben beleszámítjuk a kimondottan előnyös helyzetben lévő Pozsonyt és Kassát, az arány csupán 20,81\%-ra javul. 
3. táblázat: A déli régió aránya Szlovákián belül (2011)

\begin{tabular}{l|c|c|c|c}
\hline \multirow{2}{*}{ Járás/város } & \multirow{2}{*}{$\begin{array}{c}\text { Kiterjedés } \\
\mathbf{( k m}^{\mathbf{2}} \mathbf{n}\end{array}$} & \multicolumn{2}{|c|}{ Lakosok száma (fó) } & \multirow{2}{*}{$\begin{array}{c}\text { A magyarság } \\
\text { aránya (\%) }\end{array}$} \\
\cline { 3 - 4 } & 367,7 & 411228 & 14119 & 3,43 \\
\hline Pozsony* & 359,9 & 66265 & 9134 & 13,78 \\
\hline Szenci járás & 1074,6 & 116492 & 87349 & 74,98 \\
\hline Dunaszerdahelyi járás & 641,7 & 93594 & 32793 & 35,04 \\
\hline Galántai járás & 1100,1 & 103995 & 66356 & 63,81 \\
\hline Komáromi járás & 1347,1 & 144417 & 48483 & 33,57 \\
\hline Érsekújvári járás & 870,7 & 159143 & 9076 & 5,70 \\
\hline Nyitrai járás & 355,9 & 53286 & 16717 & 31,37 \\
\hline Vágsellyei járás & 1551,1 & 115367 & 28085 & 24,34 \\
\hline Lévai járás & 848,2 & 45562 & 10939 & 24,01 \\
\hline Nagykürtösi járás & 825,6 & 74861 & 17338 & 23,16 \\
\hline Losonci járás & 1471,1 & 84889 & 30516 & 35,95 \\
\hline Rimaszombati járás & 730,3 & 40400 & 7738 & 19,15 \\
\hline Nagyrốcei járás & 1173,3 & 63351 & 16103 & 25,42 \\
\hline Rozsnyói járás & 237,1 & 240433 & 6382 & 2,65 \\
\hline Kassa* & 1541,3 & 119227 & 11845 & 9,93 \\
\hline Kassai járás & 1073,5 & 106072 & 28145 & 26,53 \\
\hline Tóketerebesi járás & 1019,3 & 110842 & 12122 & 10,94 \\
\hline Nagymihályi járás & 16588,5 & 2149424 & 453240 & 21,09 \\
\hline Összesen & 921,58 & 119412 & 25180 & 25,77 \\
\hline Átlag (16 járás, 2 város) & 998,46 & 93610 & 27046 & 28,61 \\
\hline Átlag (16 járás) & & & \\
\hline & & & & \\
\hline
\end{tabular}

Megjegyzés: * A két város kerületeinek (járásainak) az összege.

Forrás: Saját számítás a 2011-es népszámlálási adatok alapján

Az 5. ábra a tizenhat járás statisztikai adatait veti össze Szlovákia megfelelô számaival. Az ábra oszlopai a tizenhat járás minden év decemberi munkanélküliségi rátáinak az összegét ábrázolják. A grafikon megmutatja, hogy 1997 és 2007 között, legyen ez idó alatt bármilyen gazdasági helyzet, Dél-Szlovákia összesített munkanélkülisége mindig rosszabb volt az országos átlagnál. Az utóbbi években tapasztalható általános javulás természetesen ott is érezhető, de az elmaradás továbbra is jelen van. A különbséget a görbe fejezi ki. Noha az az ábrán a pozitív sávban húzódik, mivel különbségrôl van szó, valós értéke negatív. Látható a konvergencia, ellenben arányait tekintve az elmaradás nem változik. Mindehhez még hozzá kell tenni azt is, hogy a nyugati járások - Szenci, Dunaszerdahelyi, Galántai, Komáromi, Érsekújvári, Vágsellyei, Nyitrai és Lévai - munkanélküliségi rátája 2017 decemberében már külön-külön jobb volt, mint az országos átlag. A régió egészének lemaradását a középsô és a keleti régió súlyos helyzete okozza. 
5. ábra: 16 dél-szlovákiai járás és Szlovákia munkanélküliségi adatai (\%)

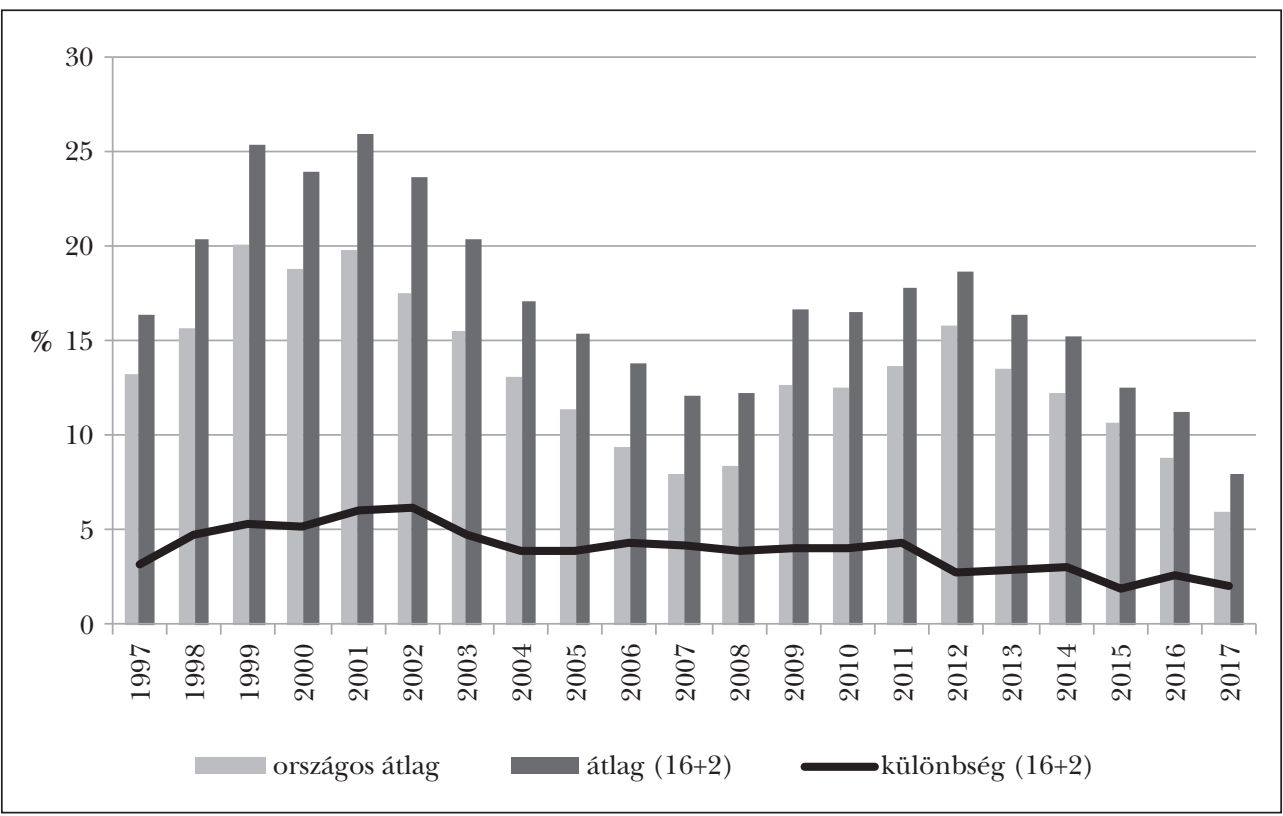

Forrás: Saját szerkesztés a www.upsvr.sk alapján

Az 5. ábra szemlélteti, hogy 1997 óta, amióta az ilyen adatok elérhetók, a magyarok által jelentôs mértékben lakott vidék foglalkoztatási helyzete folyamatosan rosszabb, mint az országos átlag. Ennek okai sokrétúek. A következókben néhány gazdasági és demográfiai tényezôt fogunk elemezni.

A 4. táblázat egyértelmúen rámutat arra, hogy ahol kevesebb a munkahely, ott a bérek is alacsonyabbak. A jó szenci adatok mögött feltehetóen az rejlik, hogy a járásból sokan Pozsonyba járnak dolgozni, ahol kiemelkedóen magasak a bérek. Arra is fel kell hívni a figyelmet, hogy az iparban kifizetett bérekrôl van szó, a szlovákiai átlagbér 2017-ben 954 eurót tett ki, így ez a mutató egyben azt is jelenti, hogy kevésbé iparosodott vidékrôl van szó.

A táblázat következó indexe azt vázolja, hogy az ország ipari termelésének mekkora része összpontosul az adott járásba. Látható, hogy a termelőkapacitások a nagyvárosok mellett a Pozsonyhoz közeli járásokba koncentrálódnak. Ez a mutató azonban nem adhat pontos képet, hiszen a magyar járások átlagban nagyobbak és népesebbek, mint az országos átlag. Ez a tény azonban csak tovább rontja a régió mutatóit, hiszen a 16 magyar járásban az országos termelés 17,84\%-a van jelen. A két nagyváros beszámításával ez az érték 27,47\%-ra ugrik, de még ezek a számok is elmaradnak mind az adott terület lakosságának a számától, mind pedig a kiterjedésétôl.

A táblázat harmadik mutatója, a termelékenységet ábrázoló két oszlop megint arra hívja fel a figyelmet, hogy a déli régióban múködő vállalatok aggregált termelékenysége elmarad az országostól. A Galántai járás jó adata mögött az áll, hogy a járási szék- 
4. táblázat: Dél-Szlovákia járásainak válogatott gazdasági mutatói 2017-ben

\begin{tabular}{l|r|r|r|c|c|c}
\hline \multirow{2}{*}{ Járás/város } & \multicolumn{2}{|c|}{ Ipari átlagbér } & \multicolumn{2}{c|}{ Ipari termelés } & \multicolumn{2}{c}{ Termelékenység } \\
\cline { 2 - 8 } & EUR & $\begin{array}{c}\text { Országos } \\
\text { átlag \%-a }\end{array}$ & EUR & $\begin{array}{c}\text { Országos } \\
\text { részese- } \\
\text { dés } \mathbf{( \% )}\end{array}$ & EUR & $\begin{array}{c}\text { Országos } \\
\text { átlag \%-a }\end{array}$ \\
\hline Pozsony & 1567 & 136,98 & 4566113095 & 5,72 & 381536 & 189,66 \\
\hline Szenci járás & 1251 & 109,35 & 252704669 & 0,32 & 137657 & 68,43 \\
\hline Dunaszerdahelyi járás & 969 & 84,70 & 656717199 & 0,82 & 131517 & 65,38 \\
\hline Galántai járás & 1071 & 93,62 & 3022137296 & 3,79 & 430013 & 213,76 \\
\hline Komáromi járás & 831 & 72,64 & 788040447 & 0,99 & 119375 & 59,34 \\
\hline Vágsellyei járás & 1135 & 99,21 & 626932019 & 0,79 & 180350 & 89,65 \\
\hline Nyitrai járás & 1052 & 91,96 & 2606936326 & 3,27 & 177019 & 88,00 \\
\hline Érsekújvári járás & 912 & 79,72 & 566131264 & 0,71 & 87743 & 43,62 \\
\hline Lévai járás & 1029 & 89,95 & 599561522 & 0,75 & 100652 & 50,03 \\
\hline Nagykürtösi járás & 625 & 54,63 & 67280919 & 0,08 & 52150 & 25,92 \\
\hline Losonci járás & 780 & 68,18 & 287530258 & 0,36 & 94730 & 47,09 \\
\hline Nagyrócei járás & 883 & 77,19 & 156799681 & 0,20 & 72509 & 36,04 \\
\hline Rimaszombati járás & 635 & 55,51 & 136596028 & 0,17 & 46005 & 22,87 \\
\hline Rozsnyói járás & 1009 & 88,20 & 406856630 & 0,51 & 160290 & 79,68 \\
\hline Kassa város & 1048 & 91,61 & 1122075898 & 1,41 & 147278 & 73,21 \\
\hline Kassai járás & 1072 & 93,71 & 959448235 & 1,20 & 253045 & 125,79 \\
\hline Tóketerebesi járás & 706 & 61,71 & 69168536 & 0,09 & 57588 & 28,63 \\
\hline Nagymihályi járás & 867 & 75,79 & 667416157 & 0,84 & 100445 & 49,93 \\
\hline Átlag (16+2) & 969 & 84,70 & - & - & 151661 & 75,39 \\
\hline Átlag (16) & 927 & 81,00 & - & - & 137568 & 68,39 \\
\hline Örszágos átlag & 1144 & 100,00 & - & - & 201164 & 100,00 \\
\hline Osszesen & - & - & 79784111942 & - & - & - \\
\hline
\end{tabular}

Forrás: Saját számítás a Szlovák Statisztikai Hivatal (www.statistics.sk) adatai alapján

helyen találhatók a Samsung gyártósorai. A vállalat Szlovákia legnagyobb cégei közé tartozik, az értékesítések alapján 2017-ben a 6. helyen állt.

A foglalkoztatáshoz szorosan kapcsolódik az iskoláztatás színvonala. A 2011-es cenzus adatai alapján Dél-Szlovákia járásai lakosságának iskolai végzettsége a következôképpen vethető össze az országos átlaggal.

Az 5. táblázat azt mutatja, hogy a régió egészében, függetlenül a lakosság nemzetiségi hovatartozásától, közmúvelődési szempontból elmaradottabb. Az alapfokú végzettséggel rendelkezôk aránya magasabb, a két nagyvároson és a Nyitrai járáson kívül 
5. táblázat: A magyar járások lakosságának iskolai végzettsége $(\%, 2011)$

\begin{tabular}{l|c|c|c|c|c|c|c|c}
\hline \multirow{2}{*}{ Járások } & \multicolumn{2}{|c|}{ Alapfokú } & \multicolumn{2}{|c|}{$\begin{array}{c}\text { Középfokú érett- } \\
\text { ségi nélkül }\end{array}$} & \multicolumn{2}{|c|}{$\begin{array}{c}\text { Középfokú érett- } \\
\text { ségivel }\end{array}$} & \multicolumn{2}{|c}{$\begin{array}{c}\text { Fóiskolai, egye- } \\
\text { temi }\end{array}$} \\
\cline { 2 - 9 } & $\begin{array}{c}\text { Déli } \\
\text { régió }\end{array}$ & $\begin{array}{c}\text { Eltérés az } \\
\text { országos } \\
\text { átlagtól }\end{array}$ & $\begin{array}{c}\text { Déli } \\
\text { régió }\end{array}$ & $\begin{array}{c}\text { Eltérés az } \\
\text { országos } \\
\text { átlagtól }\end{array}$ & $\begin{array}{c}\text { Déli } \\
\text { régió }\end{array}$ & $\begin{array}{c}\text { Eltérés az } \\
\text { országos } \\
\text { átlagtól }\end{array}$ & $\begin{array}{c}\text { Déli } \\
\text { régió }\end{array}$ & $\begin{array}{c}\text { Eltérés az } \\
\text { országos } \\
\text { átlagtól }\end{array}$ \\
\hline $\begin{array}{l}\text { Országos érté- } \\
\text { kek }\end{array}$ & 15,0 & - & 23,1 & - & 29,6 & - & 13,1 & - \\
\hline $\begin{array}{l}\text { Átlag (16 járás, } \\
\text { 2 város) }\end{array}$ & 15,1 & 0,1 & 21,3 & $-1,7$ & 29,6 & 0,0 & 14,8 & 1,7 \\
\hline Átlag (16 járás) & 18,1 & 3,1 & 23,7 & 0,6 & 27,4 & $-2,2$ & 11,4 & $-1,7$ \\
\hline
\end{tabular}

Forrás: Saját számítás a Szlovák Statisztikai Hivatal (www.statistics.sk) adatai alapján

csupán a Szenci járásban jobb az országos átlagnál. Ha a felsőfokú végzettségúek arányát nézzük, a lemaradás hasonló. A két nagyvároson kívül, amely több felsôoktatási intézmény székhelye, csak két további járásban jobbak az adatok. Az egyik a Nyitrai járás, amely szintén két egyetem központja, és megint a Szenci járás, amely közvetlenül Pozsony mellett terül el. Az érettségivel rendelkezôk aránya összességében szintén alacsonyabb.

Arra mindenképpen rá kell mutatni, hogy a probléma nem új keletú, a magyarság alacsonyabb iskolai végzettsége már a szocializmus idején elmaradt az országostól. A magyar diákok az akkori részarányukhoz képest kevesebben jártak szakközépiskolákba és gimnáziumokba, illetve kevesebben látogattak felsôoktatási intézményeket. ${ }^{3}$

A magyar nemzetiségú lakosság demográfiai adatai hosszú távon elmaradnak az országos átlagtól, így a szlovák többség átlagától is. A 6. táblázat számai alapján a természetes népszaporulatot tekintve a magyarság natalitása alacsonyabb, és a mortalitás magasabb.

6. táblázat: Természetes népszaporulat (\%o)

\begin{tabular}{l|c|c|c|c|c|c|c}
\hline & $\mathbf{1 9 5 5 - 5 9}$ & $\mathbf{1 9 6 0 - 6 4}$ & $\mathbf{1 9 6 5 - 6 9}$ & $\mathbf{1 9 7 0 - 7 4}$ & $\mathbf{1 9 7 5 - 7 9}$ & $\mathbf{1 9 8 0 - 8 4}$ & $\mathbf{1 9 8 5 - 8 9}$ \\
\hline Országos & 16,13 & 12,86 & 9,58 & 9,86 & 10,91 & 8,27 & 6,16 \\
\hline Magyarság & 13,41 & 8,14 & 5,54 & 5,24 & 6,01 & 4,64 & 3,36 \\
\hline
\end{tabular}

Forrás: Gurgyík, 1994:129, 133

Hasonló mondható el a házasságkötések alakulásáról is. Az 1960-as évek elején a magyarok házasulási viszonyszámai azonosak voltak az országos átlaggal (7,5\%o), ami aztán fokozatosan csökkenni kezdett. 1971-ben 7,7\%o volt 8,4\%o-kel szemben, majd így folytatódott: 1981: 7,4 vs. 7,8; 1989: 6,4 vs. 6,9; 2000: 3,5 vs. 4,8\%o. Ezen idôszak alatt a magyar lakosság válási dinamikája az országos trendnél magasabb volt. Amíg az elsố esetben (1961 és 2000 között) a válások száma megnégyszerezôdött, a második esetben csak megháromszorozódott. Mindezekból az is következik, hogy a magyar tár- 
sadalom öregedése gyorsabb az országosnál (Gyurgyík, 2011). Mindennek, értelemszerúen, gazdasági kihatásai is vannak.

A munkanélküliség, az alacsonyabb bérek nagy mértékben befolyásolják az egészségügyi állapotot. Már a csehszlovák idôszakban a keringési zavarok jelentették a leggyakoribb halálokot Dél-Szlovákiában. Ugyanúgy ezen a vidéken a legmagasabb a múvi terhességmegszakítás aránya, és legrövidebb a várható élettartam (Vilinová, 2012).

\section{Ös s ZEGZÉs}

A bemutatott adatok egyértelmúen rámutatnak arra, hogy Dél-Szlovákia munkanélküliségi rátája hosszú távon marad el Szlovákia munkanélküliségi rátájától. Mindehhez hozzá kell tenni, hogy Szlovákia országos munkanélküliségi mutatója mind az Európai Unió átlagához, mind pedig a V4-ekhez viszonyítva magas. A déli régió egyéb gazdasági és társadalmi mutatói úgyszintén rosszabbak az országos átlagnál. Ez mondható el a 16 járás, továbbá a két nagyváros aggregált ipari termelésérôl, átlagos termelékenységéról, az iskolai végzettségrôl, illetve bizonyos demográfiai mutatókról is. A régió helyzetének komplex elemzését jelentôsen megnehezíti, hogy egy közigazgatásilag nagyon széttagolt vidékról van szó. Ami ezt a régiót mégis egységessé teszi, az az, hogy Szlovákia magyar ajkú lakosainak túlnyomó többsége ezekben a járásokban, illetve nagyvárosokban él. A déli, magyarlakta régió 16 járása öt kerületre oszlik. Ennek a felosztásnak a hátterében jelentôs mértékben politikai okok állnak. Tény azonban, hogy a Pongrácz (2018) által felsorolt negatív munkaerôpiaci tényezők ezen a vidéken halmozottan vannak jelen.

\section{JEGYZETEK}

1 Az 1921-es elsố csehszlovák cenzus idején Szlovákiában 650597 magyar élt, ami az ország lakosságának 21,68\%-át tette ki. A rendszerváltozás idején (1991) 567296 magyar (10,76\%) élt az országban. A 2011es népszámlálás idején 458467 ember vallotta magát magyarnak, és arányuk 8,48\%-ra csökkent.

2 A Pozsonyi kerület esetében a NUTS2-es 3-as régió azonos.

3 Az SZSZK kormánya 1973/6.230 határozatának elemzése a Szlovák Szocialista Köztársaság területén élő nemzetiségekról. 1977. 12. 20. Szlovák Nemzeti Levéltár. Szlovákia Kommunista Pártja, Elnökség 1498. karton.

\section{FELHASZNÁLT IRODALOM}

Fazekas József - Hunčík Péter (szerk.) (2008): Magyarok Szlovákiában (1989-2004). Összefoglaló jelentés. A rendszerváltozástól az európai uniós csatlakozásig. Fórum Kisebbségkutató Intézet - Lilium Aurum, Somorja-Dunaszerdahely.

Gulyás László (2008): Regionalizációs törekvések és etnoregionalizmus a poszt-kommunista Szlovákiában 1989-1998. Tér és Társadalom, 22. évf., 4. sz., 189-204, https://doi.org/10.17649/tet.22.4.1206.

Gyurgyík László (1994): Magyar mérleg. Kalligram Könyvkiadó, Pozsony.

Gyurgyík László (2011): A szlovákiai magyar kisebbségi közösség 20. századi demográfiai fejlôdése. A népességfogyás okai és következményei. Fórum Társadalomtudományi Szemle, 13. évf., 3. sz., 63-80. 


\section{Horbulák Zsolt: Munkanélküliség Szlovákia déli régióiban}

Horbulák Zsolt (2019): A szlovákiai gépjármúgyártás helyzete és kihívásai. Területi Statisztika, 59. évf., 3. sz., 328-348, https://doi.org/10.15196/TS590304.

Koišová, Eva - Masarová, Jana - Habánik, Jozef (2018): Regional Differences in the Labour Market in Slovakia and the Czech Republic. Journal of Competitiveness, Vol. 10, No. 2, 104-117, https://doi.org/10.7441/ joc.2018.02.07.

Kureková, Lucia (2010): ĽLudský Kapitál: Zamestnanost'a pracovná sila. Stredoeurópska univerzita Budapešt', CELSI, Bratislava.

Leško, Marian (1998): Mečiar és a mečiarizmus. Balassi-Kalligram, Budapest-Pozsony.

Liptáková, Katarína (2017): Regionálne disparity trhu práce v Banskobystrickom kraji. Ekonomické rozhl'ady, Vol. 46, No. 3, 245-272.

Menbere Workie, Tiruneh - Štefánik, Miroslav (2014): Trh práce na Slovensku: Analýzy a prognózy. Ekonomický ústav SAV, Bratislava.

Mezei István - Hardi Tamás (2003): A szlovák közigazgatás és területfejlesztés aszimmetriái. Tér és Társadalom, 17. évf., 4. sz., 127-155, https://doi.org/10.17649/TET.17.4.920.

Mezei István (2005): Állam - ország - régió és a valóság. Tér és Társadalom, 19. évf., 3-4. sz., 187-203, https://doi.org/10.17649/TET.19.3-4.1026.

Michálek, Anton - Podolák, Peter (2014): Regionálne a priestorové disparity na Slovensku, ich vývoj v ostatnom destaroční, sústavný stav a konzekvencie. Geographia Slovaca, No. 28.

Nagy László (2015): Merre tovább, Szlovákia? Az elkövetkezendô idôszak gazdasági kilátásai. Polgári Szemle, 11. évf., 1-3. sz.

Nagy László (2016): Munkanélküliség versus foglalkoztatottság. Polgári Szemle, 12. évf., 4-6. sz.

Pongrácz Éva (2018): A szlovák munkaerôpiac aktuális helyzete és a szociális gazdaság. Munkaügyi Szemle, 61. évf., 2. sz., 38-43.

Rievajová, Eva - Klimko, Roman (2018): Regional Disparities in the Slovak Republic. In: Economic and Social Development. Book of Proceedings. 31th International Scientific Conference on Economic and Social Development - "Legal Challenges of Modern World". Varazdin, 146-151.

Süli-Zakar István (szerk.) (2003): A terület-és településfejlesztés alapjai. Dialóg Campus Kiadó, Pécs.

Švecová, Angelika - Rajčáková, Eva (2014): Regionálne disparity v sociálno-ekonomickej úrovni regiónov Slovenska v rokoch 2001-2013. In: Regionálne dimenzie Slovenska. Univerzita Komenského, Bratislava, 257-294.

Vilinová, Katarína (2012): Zdravotný stav obyvatelstva Slovenska. Univerzita Konštantína filozofa v Nitre, Fakulta prírodných vied, Nitra. 